\title{
Study on the Planning of Resettlement Areas in Southern Shaanxi Based on Landscape Ecological Evaluation
}

\author{
Dingqing Zhang ${ }^{1, \text { a }}$, Shujiao Xie ${ }^{2, b}$,Yaping Sun ${ }^{3, c}$ and Wei Guo ${ }^{4, d}$ \\ ${ }^{1}$ School of Human Settlements and Civil Engineering, Xi'an Jiaotong University, P.R. China \\ 2 School of Human Settlements and Civil Engineering, Xi'an Jiaotong University, P.R. China \\ ${ }^{3}$ School of Human Settlements and Civil Engineering, Xi'an Jiaotong University, P.R. China \\ ${ }^{4}$ School of Human Settlements and Civil Engineering, Xi'an Jiaotong University, P.R. China \\ azhangdq@xjtu.edu.cn, b446318310@qq.com, csundan0109@foxmail.com, \\ dwilliamguo@xjtu.edu.cn
}

\begin{abstract}
Keywords: Southern Shaanxi; Planning of resettlement areas; Village and town planning; Landscape ecological Evaluation

Abstract. The resettlement project in Southern Shaanxi is featured with a large amount of planning and construction in the scope of town. Due to the disconnection with the village and town planning and the lack of overall consideration on the ecological environment, problems have occurred such as the disorder of town spatial structure and ecological destruction. Based on the planning system of village and town, adopting the theories and methods of landscape ecology, the planning system of resettlement areas is constructed with the integration of the landscape ecological evaluation methods. It focuses on the resettlement area construction at a level of overall planning. And the ideas and methods are presented to strengthen the connection between the planning of resettlement areas and town planning, and to promote the coordination of the resettlement construction and ecological protection.
\end{abstract}

\section{Introduction}

Southern Shaanxi is located in the southern part of Shaanxi Province in China. It is situated in the Qinling-Bashan mountain area and has fragile geological conditions. Thus, natural disasters like mountain torrents, landslides and mudslides easily happen in this area [1]. In 2011, the government of Shaanxi launched the project of relocation and resettlement in Southern Shaanxi and a number of new settlement sites have been built. In the view of the present situation of the resettlement planning and construction in the scope of town, it aroused problems of unreasonable spatial structure of villages and brought new pressure to the fragile regional ecological environment due to following the traditional urbanization construction model and lacking the consideration of overall planning in landscape scale. The utilization of the theories and methods of landscape ecology in the resettlement area planning provides a new perspective which is helpful to coordinate the relationship between resettlement area construction and ecological environment protection in Southern Shaanxi.

\section{Landscape Ecological Characteristics and Planning of Resettlement Areas in Southern Shaanxi}

Landscape Ecological Characteristics. The landscape ecology in an area refers to a synthesis made of the natural and unnatural elements that rely on the local natural environment and provide local people with production and living service. As for the distinctive landscape ecological characteristics in Southern Shaanxi (refer with:Table1), for one thing, it represents the sensibility and fragility of natural elements such as the topography, geology, hydrology and etc. For another, it represents the negative effects and destruction caused by the unnatural elements like human production and construction. Thus, great importance should be attached to the influence of urban and rural construction on regional landscape ecology. Besides, coordinating the relationship between these two 
is also an important prerequisite for the sustainable development of local human settlement environment.

Table1 Landscape Ecological Elements and Characteristics in Southern Shaanxi

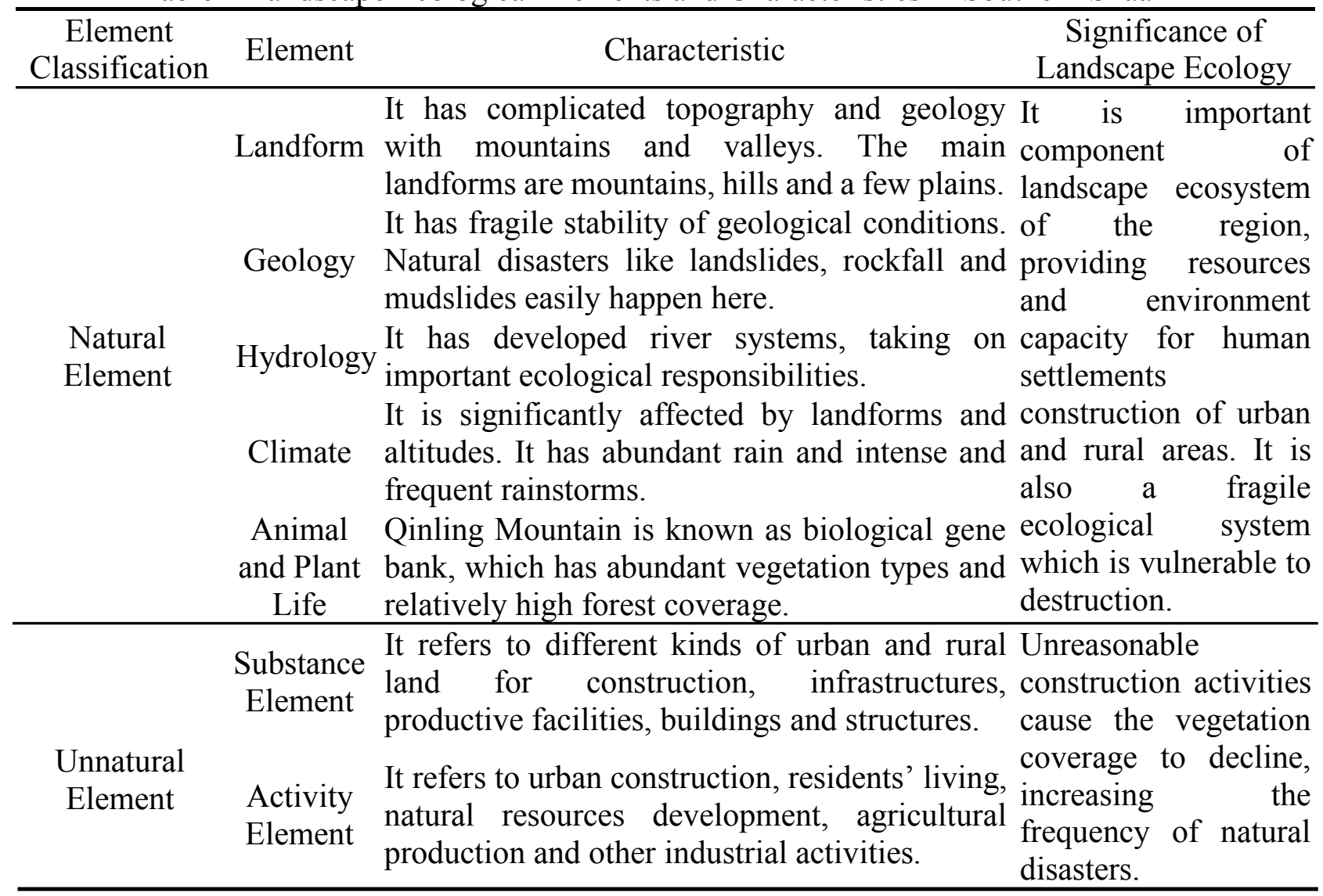

Present Situation of Planning and Construction of Resettlement Areas in the Town. The village and town system refers to the town and village groups that are connected organically in economy, society and space within the administrative region of the town. The village and town planning is the comprehensive and specific arrangements that are used for coordinating the layout of village and town and various construction. Generally, it is divided into two periods, the overall planning and the construction planning. The contents of resettlement planning in the town scope from the site selection to the specific layout are all included in the village and town planning. Not only will it change the spatial structure of villages, but also its spatial location and construction scale may cause pressure on the ecological environment.

Due to the urgency of resettlement and relocation project, the planning of resettlement areas lacks the comprehensive and overall ideas, disjointed with the overall planning of villages and towns. Especially during the process of site selection, some resettlement sites chose the relatively suitable place for the nearest settlement [2]. It brought about a result that the connection between the new resettlement sites and township and other villages are not close enough, affecting the overall harmonious development of villages and towns.

Meanwhile, centralized and mass construction of resettlement areas resulted in the rapid growth of construction land. Large amount of natural landscape are gradually replaced by artificial landscape, which caused the change in landscape structure. Some landscape ecological elements like mountains, river systems and forests of important ecological values are under improper protection. What's worse, they have been encroached by the construction land, bringing the destruction in some extent to the fragile ecological environment and resulting in the decline in the ecological stability. 


\section{Construction of Resettlement Area Planning System in Southern Shaanxi Based on the Landscape Ecological Evaluation}

Landscape Ecological Evaluation Methods. Landscape ecological evaluation is an important method in Landscape Ecology. It is used to assess the ecological environment in certain area, which is of great importance to the sustainable planning [3]. Landscape ecological evaluation has many types. According to the difference in the theme and the focus of evaluation, ecological sensibility evaluation, ecological suitability evaluation and landscape security pattern analysis can be carried out in the resettlement areas of Southern Shaanxi. Then the site selection and spatial layout of villages can be guided under the evaluation result.

Generally, landscape ecological evaluation includes landscape ecological investigation, evaluation index system, single factor evaluation and comprehensive analysis evaluation (refer with: Fig. 1). Landscape ecological investigation aims at grasping the landscape ecological elements and their characteristics and gaining the data source like statistical data, map data and remote sensing data. Evaluation index system includes selecting evaluation factors, setting standards of classification of the factor and its weight. Among them, classification standards of evaluation factors are proposed combined with the local landscape ecological characteristics and suggestions from the concerned experts. The weight should be ascertained by the impact of evaluation factors on the landscape ecology. The common method is the analytic hierarchy process (AHP). During the process of evaluation, the GIS platform is used to create the basic database, evaluating each factor one by one and forming the single factor evaluation map. And superposition operation is performed by factor weighting, forming the multiple-factor comprehensive evaluation map.

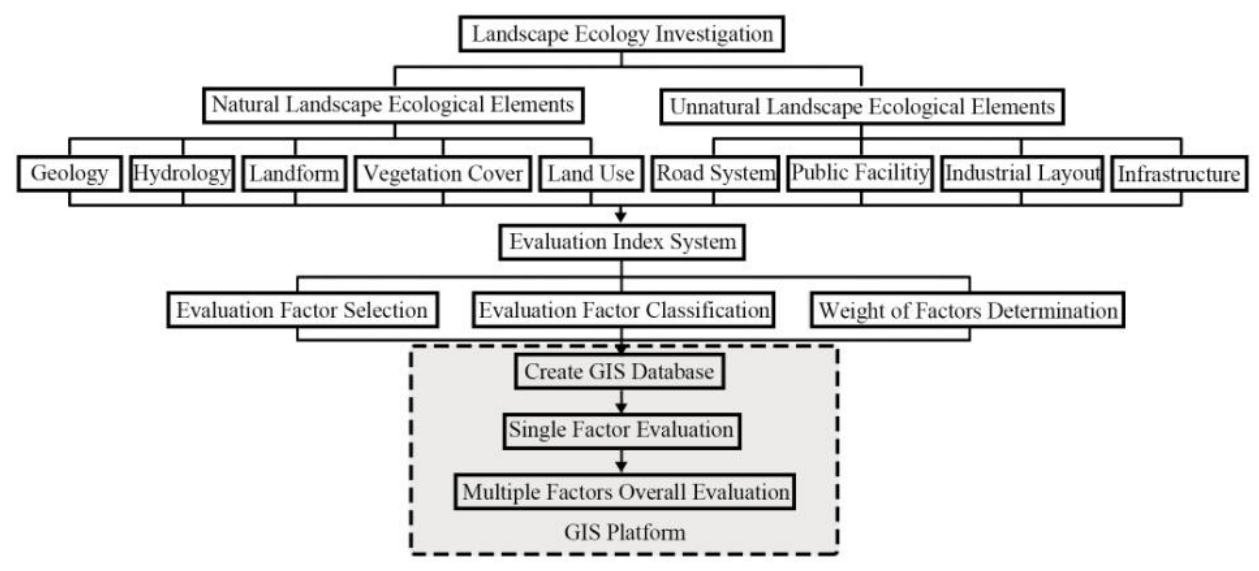

Fig. 1 General Process of the Landscape Ecological Evaluation

Resettlement Areas Planning System Integrated with Landscape Ecological Evaluation. Based on the basic contents of traditional village and town planning and integrated with the ecological sensibility evaluation, construction land suitability evaluation and landscape security pattern method, the resettlement area planning system is built to quantitatively analyze the key ecological factors of landscape by the GIS platform. The focus is put on solving problems like ecological protection zoning, resettlement site selection and spatial structure, ecological infrastructure construction at a level of overall planning. Thus the planning of resettlement areas can be integrated into the village and town planning better, improving its scientific nature (refer with: Fig. 2).

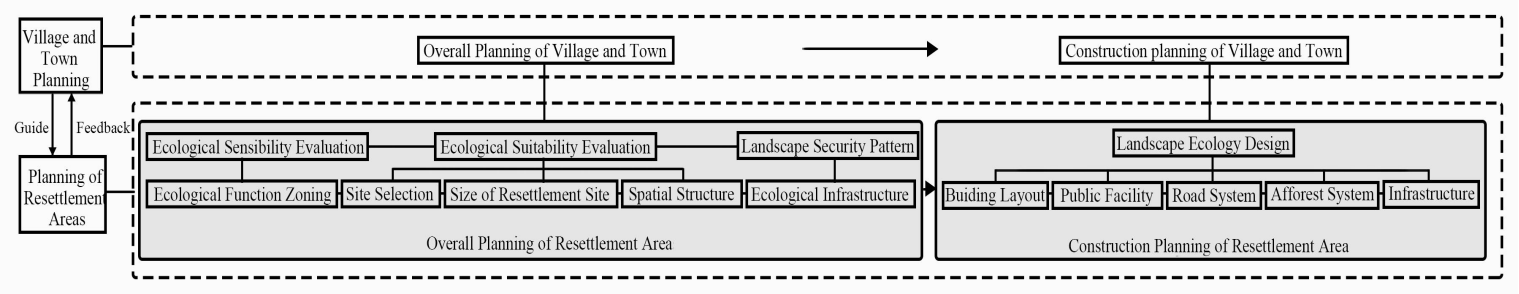

Fig. 2 Frame of the Planning System of Resettlement Areas in Southern Shaanxi Based on the Landscape Ecological Evaluation 


\section{Planning Strategies and Methods of Resettlement Areas Based on the Landscape Ecological Evaluation}

Ecological Function Zoning Based on the Ecological Sensibility Evaluation. Ecological sensibility refers to the ability of ecological factors to adapt to the external pressure and disturbance without damaging or reducing the environmental quality [4]. The ecological sensibility evaluation is an effective method to confirm the areas that should be given the preference to or be focused on the ecological protection [5]. It is proposed to divide the ecological function areas based on the ecological sensibility evaluation and come up with the corresponding protective measures and development suggestions, providing guidance for determining the construction land of resettlement areas.

The steps of ecological functional zoning based on the ecological sensibility evaluation are listed below: Ensure the landscape ecological factors like slope, altitude, vegetation and water system, constructing an ecological sensibility evaluation index system; Classify each factor by sensibility levels, and use analytic hierarchy process to ensure the weight of each factor; Use GIS to analyze the ecological sensibility by single factor; Perform weighted superposition of each factor in GIS and calculate the comprehensive score of ecological sensibility, and classify it into sensibility areas of different levels according to the sensibility comprehensive score; Combine with the evaluation result of ecological sensibility, divide the basic ecological function areas in the scope of town and come up with the corresponding construction strategy (refer with:Table 2).

Table 2 Construction Strategy of Ecological Function Zone

\begin{tabular}{|c|c|c|c|}
\hline $\begin{array}{l}\text { Ecological } \\
\text { Function } \\
\text { Zone }\end{array}$ & $\begin{array}{l}\text { Ecological } \\
\text { Sensibility } \\
\text { Zoning }\end{array}$ & $\begin{array}{l}\text { Landscape } \\
\text { Ecological } \\
\text { Elements }\end{array}$ & Ecological Construction Strategy \\
\hline $\begin{array}{l}\text { Ecological } \\
\text { Reserve }\end{array}$ & $\begin{array}{l}\text { Mainly are } \\
\text { high } \\
\text { sensitive } \\
\text { areas }\end{array}$ & $\begin{array}{l}\text { Mountainous } \\
\text { region, forest } \\
\text { land, water } \\
\text { source area and } \\
\text { nature reserve }\end{array}$ & $\begin{array}{l}\text { Implement measures to protect ecology, forbid } \\
\text { the development and construction in reserves to } \\
\text { help improve the regional ecological environment } \\
\text { and restore ecological functions. }\end{array}$ \\
\hline $\begin{array}{l}\text { Ecological } \\
\text { Control Zone }\end{array}$ & $\begin{array}{l}\text { Mainly are } \\
\text { medium } \\
\text { and low } \\
\text { sensitive } \\
\text { areas }\end{array}$ & $\begin{array}{l}\text { Hill, farmland } \\
\text { and the land } \\
\text { surrounding } \\
\text { ecological } \\
\text { reserves }\end{array}$ & $\begin{array}{l}\text { Prevent this kind of area from being the } \\
\text { construction land, develop at low intensity such } \\
\text { as ecological agriculture and tourism combined } \\
\text { with the landscape resources. }\end{array}$ \\
\hline $\begin{array}{l}\text { Ecological } \\
\text { Coordination } \\
\text { Zone }\end{array}$ & $\begin{array}{l}\text { Mainly are } \\
\text { low } \\
\text { sensitive } \\
\text { areas }\end{array}$ & $\begin{array}{l}\text { Flat ground } \\
\text { (gentle slope), } \\
\text { constructive } \\
\text { land of villages } \\
\text { and towns }\end{array}$ & $\begin{array}{l}\text { Take as the suitable area for the development and } \\
\text { construction of village and town, compensate for } \\
\text { the ecological environment during the } \\
\text { development, increase the greening rate of the } \\
\text { construction land and strengthen the continuity of } \\
\text { the surrounding ecological resources. }\end{array}$ \\
\hline
\end{tabular}

Site Selection of Resettlement Areas and Spatial Structure Planning of Villages Based on the Ecological Suitability Evaluation. Ecological suitability evaluation is a basic method that guides the site selection of resettlement areas. Ecological suitability refers to the ecological situation and development conditions of the regional land or the most suitable ecological direction of utilization of the regional ecological environment [4]. Through the ecological suitability analysis of the land in resettlement areas, it not only helps to guarantee the rationality of the new site for resettlement and relocation, optimizing the spatial structure of villages, but also helps to realize the harmonious relationship between the construction and ecological environment.

The evaluation process of ecological suitability is as follows: Determine the evaluation index system that affects the site safety and satisfies the needs of basic construction such as the surface slope, geological structure, landform and important infrastructures [6,7]; Determine the weights and classification standards of each factor; Use GIS to carry out the single factor analysis; Superpose the 
single factor according to the weights and make the overall assessment; According to the final suitability score, divide areas of different construction suitability.

It is proposed to guide the site selection of resettlement areas and control the scale of development and construction according to the range of the construction suitability areas. The land with high suitability has more stable geological conditions. It can basically satisfy the needs of construction of the residential sites [8], becoming the first choice for the development and construction of resettlement areas. The region with normal suitability usually has certain restrictions during the construction process such as undulating terrain and unstable geology. It can be considered as the land for forests and farming. The area with poor suitability which is mainly distributed in the steep terrain, slope region, belongs to natural disaster prone area or potential threat zone, or important ecological protection area. It is not suitable for development and construction.

Besides, the site selection of resettlement areas should take the overall environment and development direction of town into full consideration, especially considering the traffic connection with the township, surrounding resettlement areas and original villages and the irradiation loop of public service facilities. Thus the resettlement sites can be distributed in the suitable construction areas and at the same time it achieves the goal of appropriate scale of each residential area, reasonable spatial structure and convenient transportation connection in the town.

Ecological Infrastructure Network Construction Based on the Landscape Security Pattern. Ecological infrastructure (EI) in the scope of town means the natural system that the village and town rely on and the base of natural service which villagers can gain continuously. It includes all the green space system, forest system, farmland system and natural protected area system. It is of great importance to the stability of natural ecological process like regional biodiversity and hydrologic cycle. The focus should also be put on the overall and systematic structure of ecological infrastructure while mass artificial construction has been carried out in resettlement areas.

The construction of ecological infrastructure can use landscape security pattern (SP) analysis method. Through the analysis and imitation of ecological process, it can be determined that the landscape elements, spatial location and connection that have great importance to the security and health of this process. The ecological security pattern usually includes 5 segments, the source, buffer, connection between sources, radiation channel and the strategic point [9].

The construction process of ecological infrastructure is listed below: Analyze the ecological process that has an important effect on ecological safety such as biological conservation and disaster prevention; Analyze and simulate from a perspective of safety and health of the landscape ecological process (including natural process and humanistic process), determine the landscape security pattern of each ecological process; Overlay the safety pattern of each process and build regional ecological safety pattern, and divide safety level areas; Formulate corresponding ecological infrastructure construction strategy (refer with:Table 3) .

\section{Conclusions}

The resettlement project in Southern Shaanxi is a complicated systemic project, which covers a broad region and faces many problems. It is proposed to use landscape ecological evaluation methods to guide the planning of resettlement areas and build a planning system that both connects the village and town planning and applies to resettlement areas construction. It is emphasized to solve problems at an overall planning level such as ecological protection, site selection and improvement of spatial structure of resettlement areas. Thus, effective ways are provided for the harmonious development between resettlement areas planning and ecological environment.

\section{Acknowledgements}

This work was financially supported by the Fundamental Research Funds for the Central Universities (xjj2015129). 
Table 3 Construction Strategy of Ecological Infrastructure Network

\begin{tabular}{|c|c|c|}
\hline $\begin{array}{l}\text { Security } \\
\text { Pattern } \\
\text { Element }\end{array}$ & Ecological Infrastructure & Construction Strategy \\
\hline Source & $\begin{array}{l}\text { Linear or surface elements with } \\
\text { abundant biological species like } \\
\text { biological reserves, mountains and } \\
\text { water systems }\end{array}$ & $\begin{array}{l}\text { Forbid the invasion of natural elements, } \\
\text { protect the native species and promote } \\
\text { ecological restoration of the mountains and } \\
\text { water systems that have been destroyed. }\end{array}$ \\
\hline Buffer & $\begin{array}{l}\text { Linear or surface elements like } \\
\text { protective forest and farmland that } \\
\text { surrounds the source }\end{array}$ & $\begin{array}{l}\text { Build the protective greening system around } \\
\text { the water systems and reserves and protect the } \\
\text { source from the destruction of construction. }\end{array}$ \\
\hline $\begin{array}{l}\text { Connection } \\
\text { between } \\
\text { sources }\end{array}$ & $\begin{array}{l}\text { Linear elements like main roads } \\
\text { and shelter belts that connect the } \\
\text { adjacent sources }\end{array}$ & $\begin{array}{l}\text { Guarantee its continuity to increase the } \\
\text { connections between sources and maximize } \\
\text { the ecological benefits. }\end{array}$ \\
\hline $\begin{array}{l}\text { Radiation } \\
\text { channel }\end{array}$ & $\begin{array}{l}\text { Linear elements like branches and } \\
\text { local roads }\end{array}$ & $\begin{array}{l}\text { Improve and restore the branches of water } \\
\text { systems. Provide the hydrophilic space for } \\
\text { residents. }\end{array}$ \\
\hline $\begin{array}{l}\text { Strategic } \\
\text { point }\end{array}$ & $\begin{array}{l}\text { Point elements like parks and } \\
\text { gardens as the stepping stone } \\
\text { between sources }\end{array}$ & $\begin{array}{l}\text { Use native plants to create the green } \\
\text { recreational space in a small scale to make } \\
\text { greeneries penetrate the residential space. }\end{array}$ \\
\hline
\end{tabular}

\section{References}

[1] Haibo Lian. Preliminary Study on Suitability Assessment System for Site of Immigrant Relocation Area in Southern Shaanxi. A Dissertation Submitted for the Degree of Master, Chang'an University, 2014.

[2] Jichang Wang. Research on the Present Situation and Solutions of Immigration in Southern Shaanxi. Journal of Baoji University of Arts and Sciences (Natural Science), 2015,35(03):52-56.

[3] Xiaoming Chen, Hui Cen. Applying Landscape Ecology Evaluation in Small Town Master Plan: Tanbu Example. Planners, 2011,27(07):98-103.

[4] Luo Guo, Shihong Du, Dayuan Xue. Landscape Ecology Spatial Patter: Planning and Assessment. Beijing: China Environmental Science Press, 2009:292.

[5] Huichao Si. Ecological Sensitivity Analysis And Evaluation Of Quanjiao County Based on GIS. Planners, 2015,31(S2):263-267.

[6] Ziguang He. Study on Suitability Evaluation Method of Resettlement Location in Southern Shaanxi. A Dissertation Submitted for the Degree of Master, Chang'an University, 2016.

[7] Haibo Lian, Fasuo Zhao, Yanlin Wang, et al. Suitability Assessment System Preliminary Study for Site of Immigrant Relocation Area in Southern Shaanxi. Journal of Catastrophology, 2015,30(03):104-109.

[8] Yueting Guo, Heping Liao, Jiangang Xu. Evaluation on Suitability of Rural Residential Land in Three Gorges Reservoir Region. Transaction of the Chinese Society of Agricultural Engineering, 2012, 28(05):252-259.

[9] Wenwei Jiang, Hui Yang, Peng Sun. Green System Planning of Towns based on Landscape Ecological Security Theory-_ A Case Study of Sian in Changxing County, Zhejiang Province, China. Proceedings of the Chinese Society of Landscape Architecture 2011 Annual Meeting. Chinese Society of Landscape Architecture, 2011:5. 